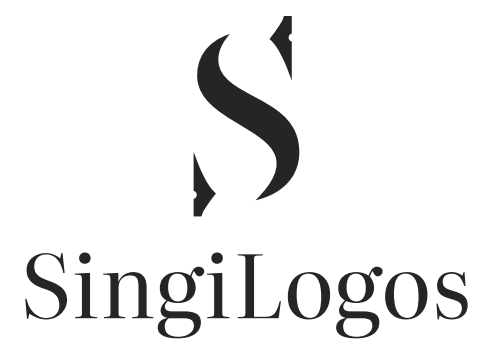

SINGILOGOS 2021, 1(1): 17 - 28

ISSN: $2812-7005$

UDK: $271.2-247.6-277.2$

$271.2-175$

DOI: $10.18485 /$ us_singilogos.2021.1.1.3

Original paper/Originalni naučni rad

\title{
ASPECTS OF THEOLOGY OF HISTORY IN THE GOSPEL OF MARK
}

\author{
Christos Terezis* \\ Professor at the University of Patras, \\ Patras-Greece
}

\begin{abstract}
:
In this study we attempt to demonstrate, according to the hermeneutical method, some approaches of Mark the Evangelist with respect to the theological reading of the historical becoming. Our cause is the parable of the evil farmers to which the cultivation and utilization of an area is assigned by their owner. This parable refers to the dialectics between God and the Jewish people, in the prospect of the earthly-historical actualization of the metaphysical providential plan. The farmers, however - who represent the leading rank of the Jewish people- choose their own ways to utilize the vineyard and, thus, they do not correspond to the dialectical call which God addressed them. In fact, they do not remain in this denial, but they eliminate those sent by God and finally his beloved Son. This continuous decision-failure makes God assign the cultivation of the vineyard to other farmers. Aplying an allegorical approach of the parable, we attempt to present which conditions relate with which relate with the soteriological intervention and eschatological perspective of God about man, so that from the "image of God" to proceed to the "likeness of God". Furthermore, we shed light on the radical openness which the Incarnation of the Son and Logos of God in the person of Jesus Christ gives with respect to the evolution of the historical becoming, on the basis of the dialectics and co-operation between the divine and human. Our final judgement is that the New Testament has revealed the axiological terms for approaching history.
\end{abstract}

\section{Article info:}

Received: April 22, 2021

Correction: June 17, 2021

Accepted: August 7, 2021

\section{Keywords:}

Mark the Evangelist, parable of the evil farmers, Theology of History, God, Prophets, Son of God, hermeneutical method.

\section{INTRODUCTION}

In this study, I will apply a specific approach of the Orthodox Christian teaching, using as a starting point the allegorical meaning of a parable that is included in the New Testament. In general parables are texts which are parts of the semantic and with teleological-eschatological foundations orientation of Jesus Christ's words, which aim 
to make more accessible the general and particular positions of their content as well as rendering the topic more applicable while motivating their morals at the same time and motivating their morals in direct time'.

The length of a parable is short and its purpose is to prevent the audience from falling into meaningless or even maximalist detailed reductions, so as not to lose the rational line of thought and the crucial extensions of the topic elaborated. Nevertheless, the short length of a parable also serves another goal: how a topical subject will be connected with what is expected to take place, in the sense of how the historical time of this world will communicate with the meta-historical function of the Church and the hyper-historical eternity of the revelations of the Holy Trinity through the initiation into the Person of Jesus Christ. So, to appropriately comprehend its content, an auditor needs to activate a transcendent hermeneutic capability.

In the spiritual context of the New Testament parables are used by the Synoptic Evangelists usually to present the well-known allegorical narrations of Jesus Christ's teaching or to express a proverb or a saying, a comparison between opposite things, an example to follow or to avoid. An intense world with a number of directions arises. It should be mentioned that the parables of the Gospels are almost completely different from the didactic myths of the Ancient Greek Literature, since the suggestions made by their writers, who have many memories from the person and teaching of Jesus Christs, regardless of their secular intervention, have divine or at least metaphysical specifications. By extension, their quality is analogous to Jesus' personality as a God-man, who is projected by them as their natural exponent. They generally follow a different rationale compared to what analogously precedes as well as the special directions of a new theological and cultural approach -both of which are basically expressed by thinking, capable of making decisions, united and acting persons- whose purpose is to transform both themselves and their fellow men. In a broader sense, we have to mention that, even though the reading of a parable begins from the expressive means used in it, attention constantly turns to their spiritual-theocentric requirements, in order that these means eventually express the distance from everything they would show in a typically declarative way.

Therefore, the main topic of the parables is God's kingdom, in the sense that it crucially intervenes in Jesus Christ's person, that is, the incarnated in time and space divine Logos, whose purpose is men's existential plenitude and their conscious and active in practice acceptance of this prospect. In this context, the call for repentance or for reconsidering their thought and actions is quite intense, in order to become in the future

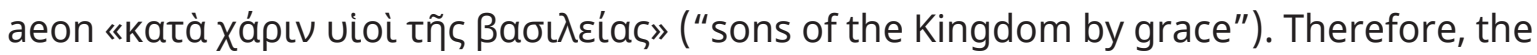
prospect of the progression from the "image of God" to the "likeness of God" dominates and the emphasis re-given to the development of man into god by grace is the gospel of the new times, which are to come while at the same time are already here, according to John the Evangelist. That is to say, it is doubtlessly necessary these times not be kept as an expectation or a transcendent plan in an unknowable idealistic metaphysical level, but to come through the specific historical moments of the story of human adventure.

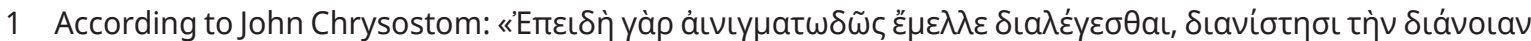

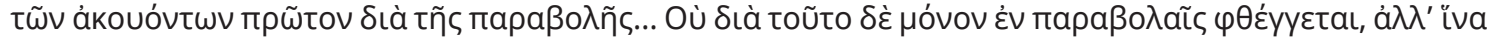

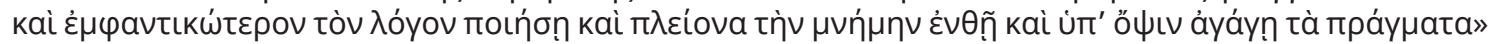
(Commentarius in S. Matthaeum Evangelistam. Homilia XLIV, P.G. 57, 467.17-24). 
In this sense, what is even more confirmed is these parables also hold a crucial historical-social role, which is expressed by the Church and its renewing course. In this context, they rationally rely on axiological criteria as well, which come from the meaning of the sending of Jesus in men and how their content is renewed in many ways into the historical becoming, so that to come into a dialectical communication with any spiritual or bio-theoretical worldviews appeared².

In this study, the subject of our investigation is the parable of the evil farmers from the Gospel of Mark, 12.1-123. This is a parable delivered by Jesus Christ when the archpriests, scribes and the presbyters of Jerusalem asked him: a) under what power does he perform these actions and b) who gave him him this power? Jesus does now answer for himself and asks them if the baptisms of John the Prodrome were defined by God or man. The representatives of the Jewish religion answer that they are not aware of this so that to avoid the obstacles of the question. Jesus Christ points out that neither would he answer their question. The next thing is to deliver this parable. I shall approach the text of the parable in the allegorical method and my purpose is to bring into surface what would be defined as Theology of History from a Christocentric point of view, which appears through the development of the Church, which introduces the gospel of a new reality. This reality is clearly opposite to the Jewish status quo, which led Jesus Christ to crucifixion, while the ancestors of this status quo had eliminated the Prophets in many ways.

\section{ELABORATION OF THE PARABLE OF THE EVIL FARMERS (MARK 12, 1-12)}

The parable points out the general hermeneutical and axiological context of the broad extent of the sin of the Jews, who disdained God's previously favorable mood towards them and refuted the blessing and the soteriological prospect that Jesus Christ offered them at a specific point in time. It particularly presents the responsibility of the masters the Jews, who took advantage of their position to commit crimes, and somehow foreshadows their punishment for any sort of abuse of authority they made, in which the hermeneutical ones are also included. Doubtlessly, the morals of this parable have a general application and refer to anyone who deviates from the proper understanding and use of the power which they possess, which for the Christians are considered as a duty of service but not as exercise of power.

2 All the hermeneutical Fathers of the Church, both those of the historical-grammatical School of Antioch and those of the allegorical School of Alexandria, dealt with the parables. As a typical example of the special directions, one may see the following explanation of Origen, in which a parable is discussed, as addressed a wide audience in an external place, from the similarity or likeness, which is called upon the

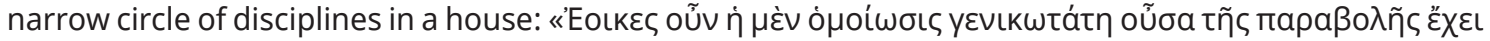

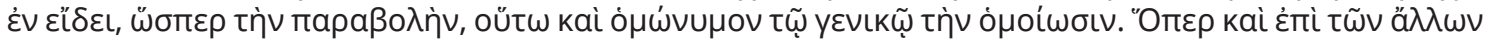

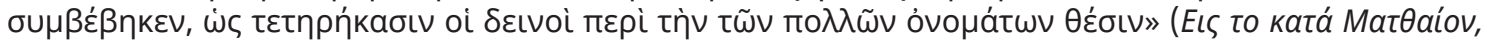

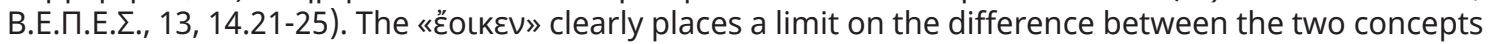
and in this way it places in a common direction both, which is related with God's Kingdom or Heaven, for which the men who Jesus Christ spoke to did not have the appropriate knowledge or maybe not even the slightest suspicion. Either way, however, the relevant narration show a radical tone, since what is attempted to be described in the current linguistic schemata is the apophatism which covers the divine. We need to add here that Origen, when it comes to these distinction, relies on the following quotation

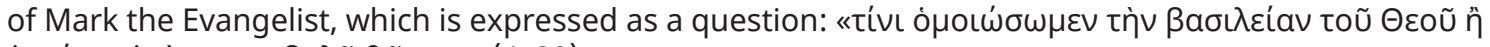

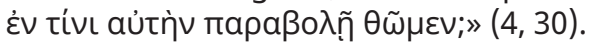

3 Generally on the parables of Mark the Evangelist, cf. Donahue 1988, 28-62. 
Specifically, the content of the parable is as follows. God is the person who planted the vineyard, that is to say he is analogously the metaphysical factor that founded on Erath the first Church of the Old Testament, which was composed of the people of Israel. God intervened in history in many ways, for example, he set free the Jews from the captivity of Egypt and brought them to the Land of Canaan. He placed them there to become a productive power, just like a properly farmed vineyard, in order to make good things, in opposition to other populations. He actually provided them with all those great elements, which, if they were used properly, would make them pious people

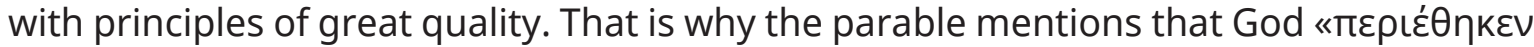

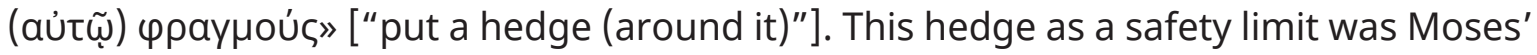
law, under the principles of which -that is to sya, the strict in accuracy suggestions for life- God cut off the Jews from the pagans, so that to be protected from any harmful effect. Furthermore, the law made them build a wine-vat, namely a sanctuary, and a tower, that is to say a temple, to worship God and perform their religious and virtuous acts. So, a metaphysical factor undertakes the responsibility to set limits on what should be chosen and rejected, but without imposing them necessarily. It suggests the terms of what is possible to be accomplished. So, this is where the causes of self-determining power are set.

Therefore, God gave this vineyard to paid tenants. In an allegorical sense, we would say that God trusted the governance and education of the people of Israel to the archpriests and masters by assigning them a highly demanding mission. This meant that they had to work for the general prosperity of their people, so that to succeed in the honorary responsibility which was rendered unto them. After God gave in the mountain Sinai the law and settled the way of function and leadership of the Jewish community, he withdrew from direct action in order people to develop in free terms and according to their own choices the possibilities which they had received as a gift. And even though he, as the absolute transcendent being, realized the first violations on behalf of the administrative power, but in an early stage, neither did he intervene nor did he impose punishments, since mistakes are something to be expected at the beginning of a new assignment, at least due to inexperience ${ }^{4}$.

But, as it was historically reasonable and necessary, the Jewish people need in an appropriate time to overcome the first inexperience and to present the results of their course. In the meanwhile God was sending Prophets, who correspond to the "slaves" of the parable. This mission meant that the Jews need to remember their duty, it was a somehow renewal of the agreement with them. The Prophets asked their compatriots to repent and do good things. This call did not have an extreme maximalist character, since it was placed in the context of behavior and intervention that would completely correspond to the true human possibilities. In fact, God did not make excessive demands, since he supported them analogously in order to succeed in their mission. So, a possible objection that the virtues projected in the Holy Scriptures is out of human capacity and non-feasible would be unsubstantial ${ }^{5}$. Besides, for their actualization the Church holds the key.

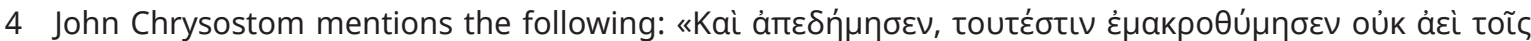

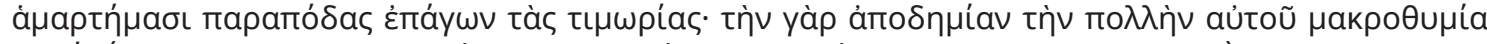

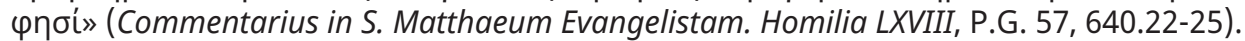

5 For an allegorical approach of the slaves as Prophets, cf. Taylor 1963, 472-474. 
Nevertheless, the answer and the behavior of the farmers to God's emissaries were literally indifferent and negative. Jesus Christ himself describes with immediacy and unpretentious historically-founded arguments the unappropriated and infertile attitude that the leading rank of the Jews had shown for a long time to the Prophets. Through the narrations of the Old Testament we actually learn that all the Prophets were placed on the margins of the Jewish community in a hostile, insulting or even criminal way. For instance, Jeremiah was thrown into a well, Isaiah was killed in a heinous way, Zacharias was stoned, John the Baptist was indifferent to the archpriests, only to be beheaded by Herod. So, the fact that they reminded the truth and pointed out their sins caused an explosive hostility and their radical expulsion from the social body. Nevertheless, God's forbearence is endless. He constantly offers the possibility for repentance and salvation. This is exactly the meaning of the frequent appearance of the Prophets, who work essentially as authentic criteria of evaluation of the historical becoming and transformation of the personal-collective and historical decisions, in order the gospel of the transformation and final salvation to be actualized ${ }^{6}$.

When God realizes that essentially there are no other intra-world means and that the call for changing behavior has no result, he makes a metaphysical decision and sends his Son. Once again, he has a pure favorable mood and as the owner of the vineyard waits for a different behavior from the farmers towards his Son. As the inheritor-owner the Son seems that he has expectations as a man, despite the fact that God knew what the Jewish people's behavior would be. Their behavior should reasonably change, since the Son was far away from the Prophets regarding his spiritual range and moral power. It should be actually mentioned that the Prophets are named "slaves" while he is named "Son". His presence would hopefully cause a new attitude, a new interpretation, recognition and conscious subordination, in the sense of order and succession. But, instead of these, the Jews do something more extreme than the most inconceivable imagination could capture, revealing in this way the explosive range of human malice. They decide to kill him, refuting his soteriological message. The heads of the Jewish community arrest Jesus and lead him with concise procedures to crucifixion, by doing the greatest injustice against the person who was the absolute expression of justice and divinity? We are facing a complete projection of a dialectical contradiction, since the person who should be the only axis of reference and meaning and was the only maturation term of the historical act is rejected ${ }^{8}$.

6 Dim. Trakatellis mentions in the relevant elaboration that this parable is connected with Christology of passion and relates the Messiah's passion with preceding forms of the Old Testament. These are the special persons that God sends, who in this way reveals His firm decision to preserve His communication with His people. Cf. Trakatellis 1983, 182-183.

7 On the intertemporal criminal behavior of the farmers as well as the messianic meaning of the term "beloved son", cf. Persch 1991, 217-220.

8 Dim. Trakatellis, commenting on that God does not send anymore servants-Prophets but the "one", his "beloved son", the "heir", mentions that the Messiah's passion appears in a relation of continuity and discontinuity with the past of the people of God (cf. Trakatellis 1983, 184). The transition from the prefigurations of the Old Testament to the Revelation of the New Testament is projected through the "son". History receives now a new meaning and God not only provides for the world but is also present. 
According to the parable, the lord of the vineyard will not leave without control the hostile farmers and will ask the reason why they performed these illegal actions. The time of tolerance and patience reaches its end and the time of blame comes. The condition of tolerance does not necessarily lead to oblivion, since this would empower evil which would eliminate the property of the good to be actualized. The moment of the critical evaluation is unavoidable. Having this in mind, Jesus askes the archpriests how the farmers should be treated. And they give the right answer. They say that the lord of the vineyard has to overwhelm them -or at least to ignore them- and give their land to other farmers to cultivate it, who will correspond to their agreement. This is a somehow prophetic answer, since history proved that the Jewish people through their internal contradictions were lead to self-punishment and to a long period of slavery, giving the leading historical role to other people. Either way, they were not close to God.

From a historical point of view, we could say the following: the vineyard of the parable, that is to say, the Church which Jesus Crist founded, is now the responsibility of new ethnic and cultural formations, to accomplish its historical role. The illegal actions of the Jews could not stop the actualization of God's plan with respect to the historical becoming. Responsibility is transferred to individual or collective initiations that manage to conceive the meaning of the combination of the metaphysical with the natural and the hyper-historical with the historical. A theological approach of the historical course arises here clearly, in the context of which the rational and sober hermeneutical attitude before all those which exist and take place is of main importance. That is why Jesus asks the archpriests if they have studied and understood the words of the Old Testament. This is a crucial question, a challenge for understanding and taking their responsibilities as well as a basic point so that to identify the causes and the degree of their self-punishment, that is to say their historical infelicity. So, he places them before their failure to communicate with the divine plan, so that to realize their aberration from the divine-form development of the cosmic history by grace. By extension, the entire discussion also becomes theological, hermeneutical and axiological.

We need also to add that those who throw the stone according to the parable, since they considered him as unworthy and unsuitable for the building, are the workers in the vineyard, for the Church is characterized as God's building. So, the leaders of the Jews, who were set as the builders of his Church, show contempt for Jesus and send him away, claiming that he has not been sent by God and that he misleads people. They do not offer Jesus even the slightest part of that building while they also spread propaganda to the people to stop the transition of his teaching. And just like the builders break and throw away any stone they consider useless, so as to not be an obstacle in their work, similarly the heads of the Jews put to death Jesus, to eliminate any "danger" that would come from him with respect to that which they intended to build. Nevertheless, their attempt was pointless and the course of history proved the opposite. The divine plan was not aborted and Jesus founded strongly Church.

As the parable develops it becomes clear that God removes from the archpriests the responsibility of his Kingdom as well as any other privilege that he gave him back in the era of the Old Testament. This removal is defined and justified here as well by their failure to utilize the chosen stone, that is to say, the essential possibility for changing the 
historical and social course. In addition, their sterility turned into a criminal intervention. And this is where the greatest point of history is set between the past and the future. So, since Crucifixion historical responsibility is assigned to anybody with no distinction, provided that he has faith and that he is united with the others through the love that Jesus Christ evangelizes, who founded strongly the Church on the stone that was rejected. Therefore, whoever evaluates negatively and rejects the chosen stone is excluded from the Gospel of the new times which is established in history. He essentially excludes himself. Criticism and self-criticism are an unavoidable historical necessity. Selfishness and persecution mania that characterize the archpriests' behavior have to be expelled from society, so that new models of life to be adopted and the new historical subject to be prepared in fundamental terms, which will refer to new ideas, will actualize new values and will cover in good criteria new needs. So, we face the beginning of the soteriological times ${ }^{9}$.

\section{HERMENEUTICAL EXTENSIONS}

Extending our elaboration, we could argue that Mark the Evangelist through his concise parable on the evil farmers reveals a historical course of many centuries, which showed the reason of the transition from the Old to the New Testament. This transition does not only refer to two texts that describe events but also to the requirements which formed and shed light on particular modes of existing and behaving. Therefore, they are texts which are built on the presence of main characters, their decisions and actions, which means that we are facing personal-centered narrations that reflect a general spirit, which, considering the way in which we need to act, will be deterministically replaced by a different one. This spirit is part of the whole perspective of how a gift given by God is interpreted and utilized by man. So, we could actually contend that here Mark the Evangelist describes a general detail of the dialectics between the divine and man as it develops in history. Taking into account all these, we have the tools to contend that the parable presents metaphysics of immanence -and not only in one episode- or, in other words, the divine historical Revelation, which is called upon man. Through the description of this adventure -as it dramatically develops through the fast-moving narration- we see a narrative style in which the field of Theology of History is formed, that is to say, a way of approaching the area of space and time in the terms that exceed it and give meaning to it. ${ }^{10}$

The fact that the parable can be also approached in an allegorical sense helps us to understand that it is composed by human behaviors of great value, mostly in a collective level, as well as by sensible things, which express a number of situations which reflect

9 For a general approach of the divine Revelations in the Gospel of Mark, cf. for instance Lamarche 1976, $26-46$.

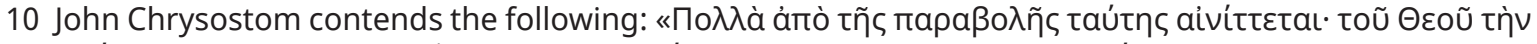

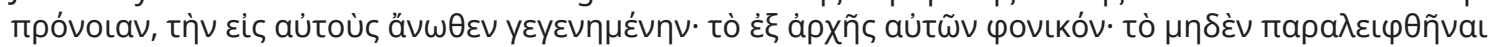

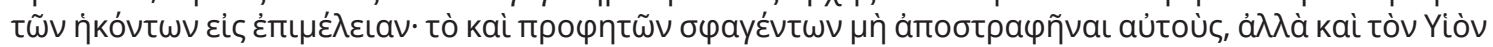

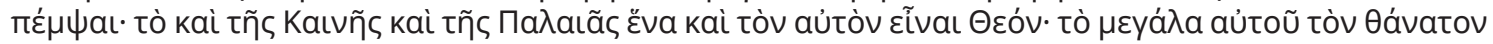

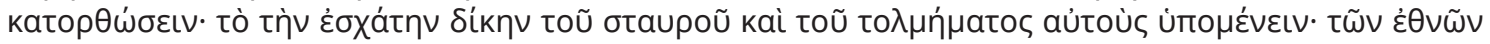

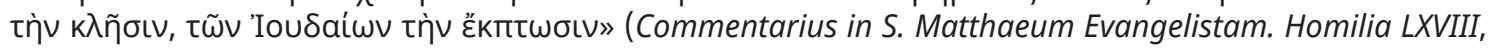
P.G. 57, 639.41-50). 
God's providential plan for man and more specifically here for the people of Israel. So, this is not an abstract or idealistic Theology, but a Theology that is formed in practice and is led to the production of concepts, conceptions and meanings on the occasion of the events. The conclusion which theoretically is drawn is that theological and historical realism dominate, therefore the beginning and the development are not defined by an a priori regulating order of values but the opposite: practice as an example or counterexample is the beginning for the formation of theory ${ }^{11}$.

In addition, the narrative style of the parable is particularly successful and reveals a completely thorough spirit of constructions, which allegorically will lead to the absolute architect. Specifically, the tower could be considered as the building in which human beings will form, through the appropriate thoughts, the value code of their selfhood, the stability of their intellectual and moral virtues. The vineyard could be associated with the external field of action, where the virtuous conditions will be applied in a creativity prospect through their performances. The "barrier" which has been built is not actually an obstacle but defines the limits of human activity, the field of the possible personal responsibility. How these limits will be manifested in thought and practice is exclusively men's decision, who are considered under the idiom of farmer, which will be confirmed as such by the production of the fruits. The parable here is prudent. As it directly arises, it does not exclude that some fruits have been produced, but it focuses on the parameter of ownership. The farmers are governed by the mentality of a highly imperialistic capitalist attitude with not virtue, which deifies the subjective possession of productive powers. Attention should focus on the fact that the criterion of the farmers' behavior is how they interpret "inheritance". Instead of adding to it the function which is related with the principles of law, they ignore it and commit brutal crimes. So, we must not exclude that here Jesus Christ exercises critique to how money economy is approached.

The Prophets suffered the repercussions of the farmers' behavior - mostly the leading rank of the Jewish people, since the farmers are presented as having a responsibility institutionally defined after delegation. By extension, these actions lead to the fact that the Jewish people face inner contradictions, since they are not guided by the spirituality which the Prophets represent, which express its traditional principles. This is where God takes a second -after the building of the vineyard and the tower- historical role, who both in himself and in practice is characterized by love. However, before the new circumstances the farmers deny to form in terms of justice their behavior and commit crimes, in fact against the authentic heir. The result is that they lose their responsibilities for forming history, which now are assigned to new nations, that is to say, according to the broader context of the New Testament, to anybody participates in the Greek lifestyle and culture, namely, in an open universality.

Nevertheless, in a strictly biblical approach of the parable, we could contend that the vineyard is the Paradise, while the tower represents, through a pre-reading, anything stable that will arise from a careful farming of the vineyard and the good use of its products. Besides, the text does not give enough information for the tower, which we would argue that it is covered by some elements of agnosia, that is to say, it is included in apophatism.

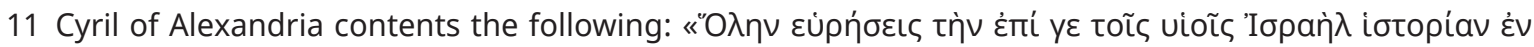

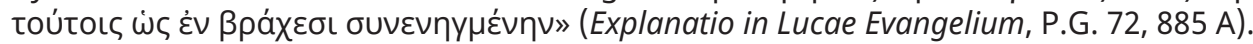


The tower is the integrity and defines for the entrance in its area a complete existential presence (diligence), as conscious participation in the greatest points of the decisions and actions. So, we need to pay attention to this combination: a) the vineyard dominates the entire description, even when it is given for farming to other farmers. b) But in the

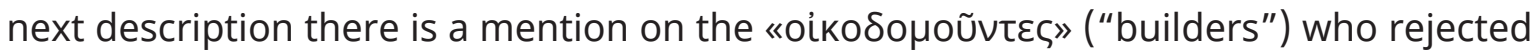
the not defined stone in the first place, which later was the basis for a different building. Combining these, we would argue that the farmers did not understand the prospect of an already built tower but of a tower under construction. However, the process of building that was their responsibility took place with only their materials, which were completely the opposite from the one and only material which the Lord used in an excellent way, so that to construct a building artistically and aesthetically great. So, the Paradise comes once again to the fore, in fact once and for all, under the authentic understanding and application of what was initially defined. Or, otherwise, the prospect and the axes of its actualization were originally set.

We also need to mention the conceptional-semantic development of the Son into Lord, which shows the transition to a new historical reality, defined by the gospel of the new times, which does not accept the spiritual and religious leadership of the Jews. The positions are explicit for the new circumstances which change what has taken place into the dialectically opposite. The "stone" that was rejected now becomes the "head of the corner", that is to say, the theandric Christian Church, which is founded by Jesus Christ, who is characterized as the one who receives the Father's love. He also intervenes as the final one, a term which specifies the content which eschatology will have, the greatest point of Theology of History or the expression of meta-history. Therefore, the current historical reality is divided into two levels, the one before Christ and the one after Christ. So, the parables do not just express morals ${ }^{12}$. And that is why they should not be approached exclusively on the basis of the historical-grammatical method.

\section{EPILOGUE}

Completing what we elaborated, we need to mention that the parable of the evil farmers is not just included in what is exclusively defined as inflexible metaphysicaltheological realism, in the sense that what is said about God cannot be interpreted. Mark the Evangelist follows a flexible model of approaching. He clearly does not exceed metaphysical-theological realism, since anything that he mentions is Jesus Christ's words, the words of the incarnated Son and Logos of God. But, from this point on these words as statements develop into concepts, communicative means and meanings. However, understanding this development depends on that the divine providence and plan for man and history has been explained and experienced by the listeners-readers. Thus: a) the fact that God becomes a man and includes himself in the processes of time and

12 Cf. Hegel 2013, 68-69, where he mentions that the parables are not just morals, but their content reveals the historical, the becoming, the course of being, eternal, living. Furthermore, he contends that the parables do not refer to inner beliefs about virtues but mostly show the supernatural illumination and the regeneration of man. 
the boundaries of space raises the terms-challenges for understanding him. b) Thus, understanding will take place on the basis of the procedures that the process of selfawareness of man establishes with the criterion of what God represents and announces. So, it will take place in the light of a deep self-criticism. c) Since self-criticism requires a good approach of the preceding historical fields, we need to decide on the causes of the interpretations. These are defined by God himself as a suggestion for a new historical time and a new historical subject. All these were clearly not accepted by the farmers, going back to the deep historical past. Therefore, they were led to a somehow subjective secularized realism, independent from critical approaches, evaluations and new interpretations.

The content of the parable of the evil farmers refers to what is defined as supernatural or historical Revelation. This is a kind of divine Revelation which is presented suddenly during historical development in specific persons (for instance, Prophets, Jesus Christ) and events. With this intervention God appears in time aiming at adding to History of a nation or of all the mankind new directions for the actualization of eschatology. We need also to mention that this parable is mostly characterized by its allegorical content and can be included in the hermeneutical choices of the theological School of Alexandria. It takes the reader from the holy texts themselves to their spirituality and reveals God's plan for man and history. The allegorical method makes possible the intertemporal presence of the Holy Scripture and its possibility to empower spirituality all historical periods ${ }^{13}$.

If we attempted, however, to stress an axiological theological approach of History according to the parable of Mark the Evangelist, we could contend that, when Jesus Christ calls upon the leading rank of Jews, he follows a monistic criterion, since he sheds light on God's uniform plan, which aims at the actualization of the historical unity in specific divine-form qualities. These are qualities of a constantly common experience. In fact, God does not intervene through his appearances in an inflexible way but in various ones. That is to say, his critique is particularized, regardless of whether the goal is one, namely, the restoration of the human course so that to open once again the path towards the "likeness of God". So, the critique exercised here functions under the pair "one-multitude", since the process of bringing back the Jews to the right according to God behavior is attempted in many ways, the most important of which is the incarnation of the divine Logos in the person of Jesus Christ. Or, otherwise, we do not meet a pluralistic relativism but the pluralism of the ontological integrity which is historically expressed. So, through Jesus Christ's presence one understands what the content of the historical becoming should be and how man is asked to understated himself as an active in many ways -but towards one direction- historical subject. Therefore, the Jews are presented as having formed a community that has been led to its historical failure, while Jesus Christ will suggest and will found a radical meta-community. Finally, we need to mention that our investigation has nothing to do with how aspects of successive readings of a biblical text meet, but the text itself primarily projects what one could define as Theology of History. 


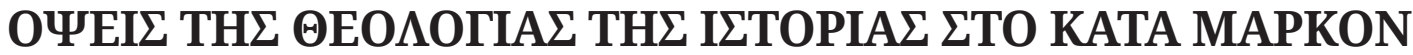 EYAГTE $\Lambda$ ION}

\section{Summary:}

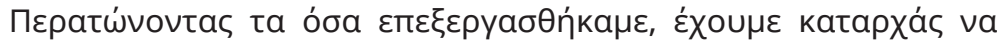

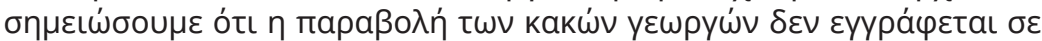

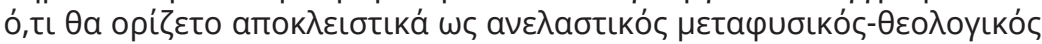

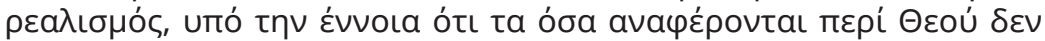

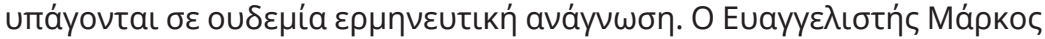

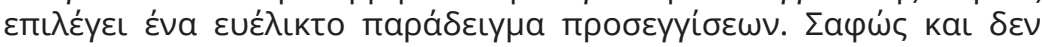

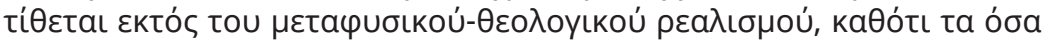

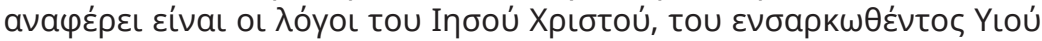

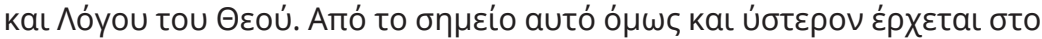

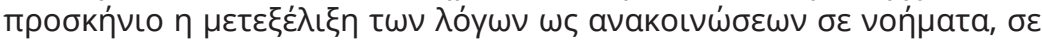

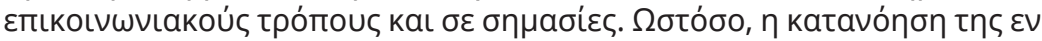

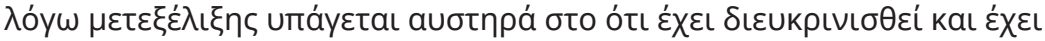

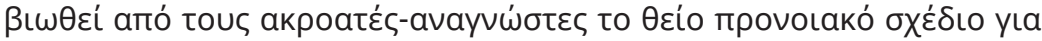

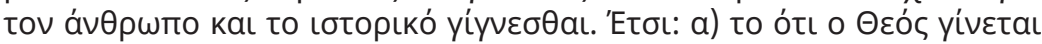

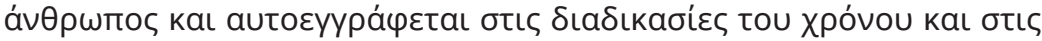

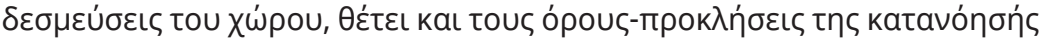

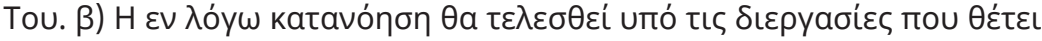

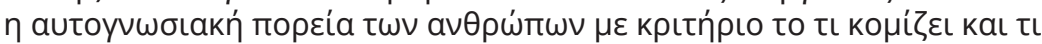

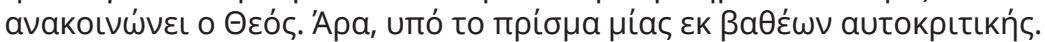

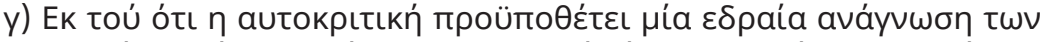

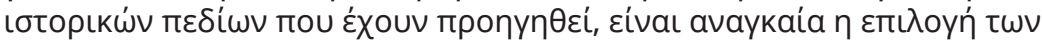

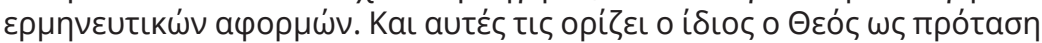

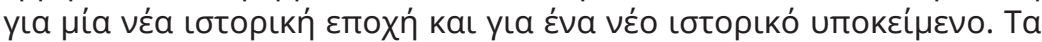

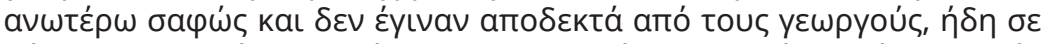

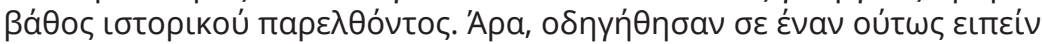

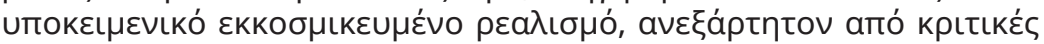

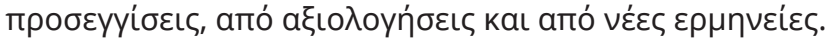

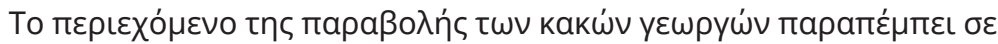

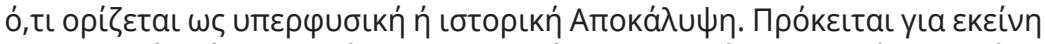

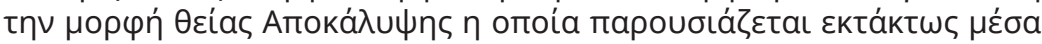

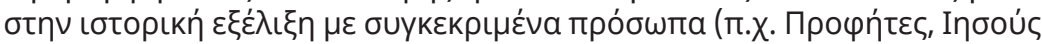

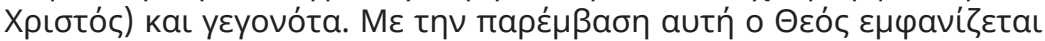

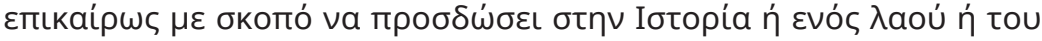

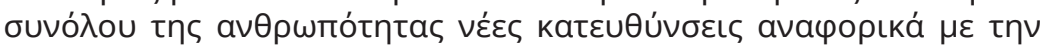

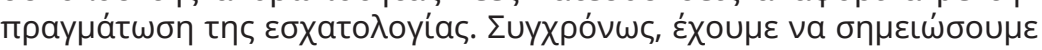

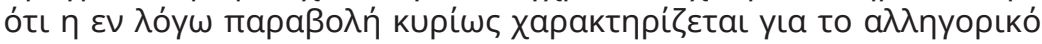

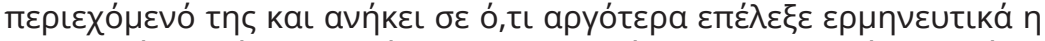

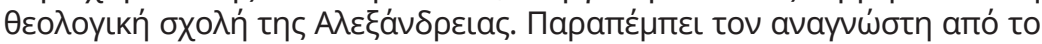

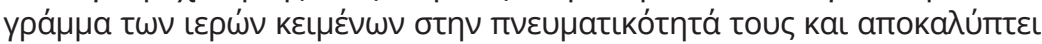

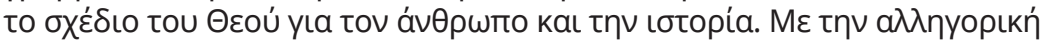

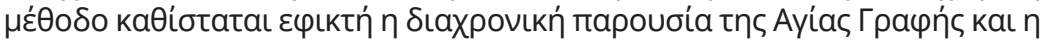

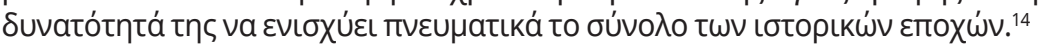

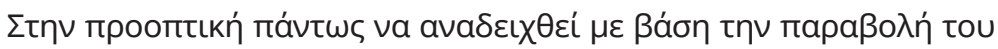

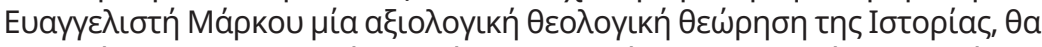

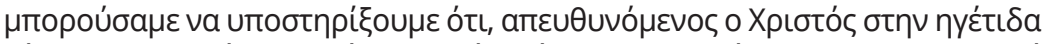

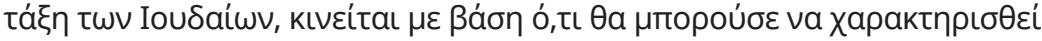

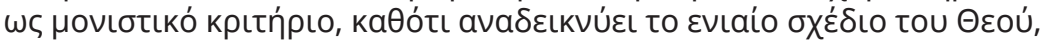

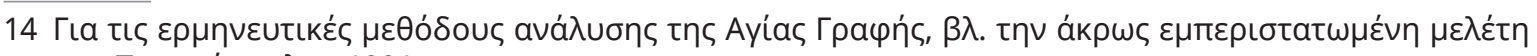

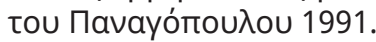




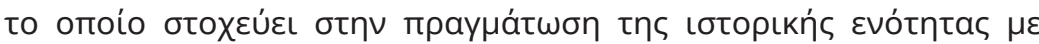
б

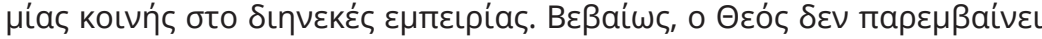

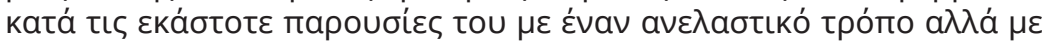

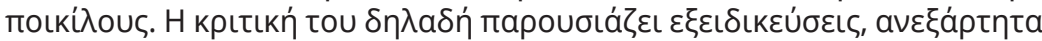

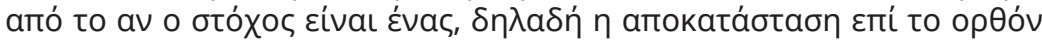

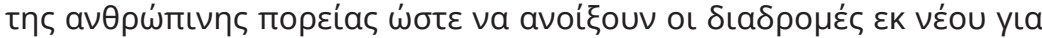

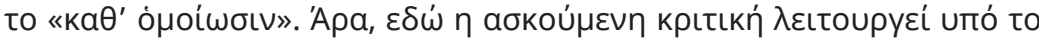

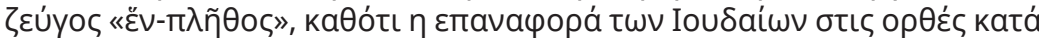

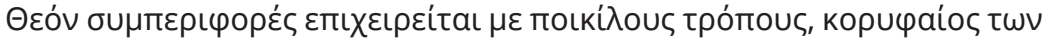

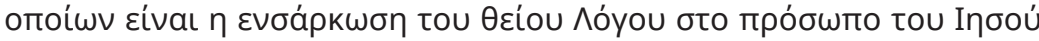

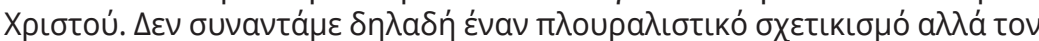

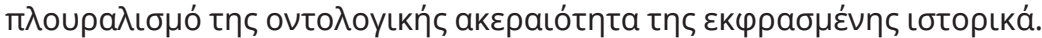

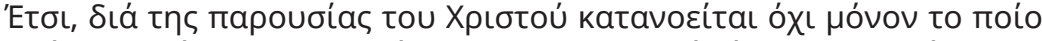

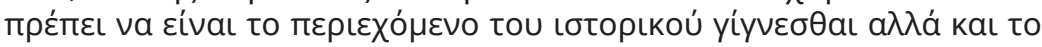

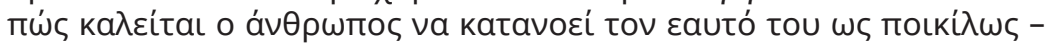

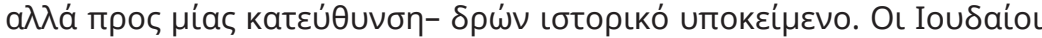

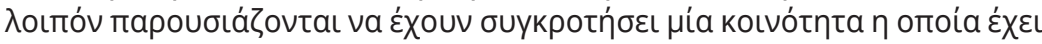

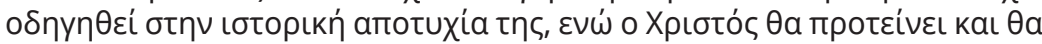

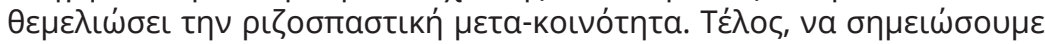

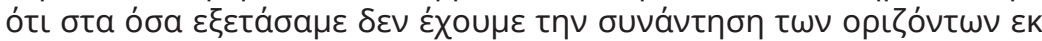

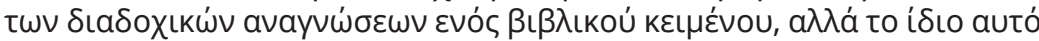

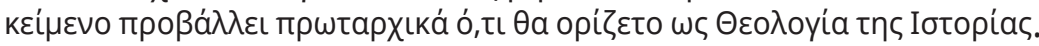

\section{Keywords:}

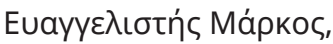

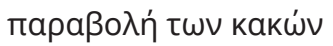

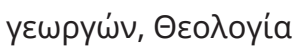

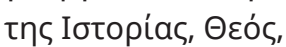

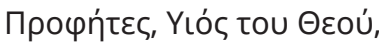

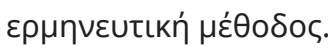

\section{BIBLIOGRAPHY}

Donahue J. R. (1988): Metaphor, Narrative, and Theology in the Synoptic Gospels "Fortress Press", Minnesota.

Lamarche P. (1976): Révélation de Dieu chez Marc, "Beauchesne”, Paris.

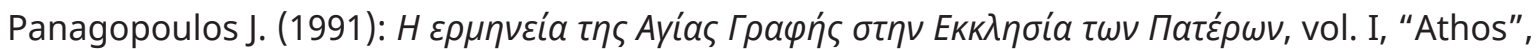
Athens.

Persch R. (1991): Das Markusevangelium, II, "Herder (Freiburg, Basel, Wien)", Freiburg.

Taylor V. (1963): The Gospel according to St. Mark, "Palgrave Macmillan", London.

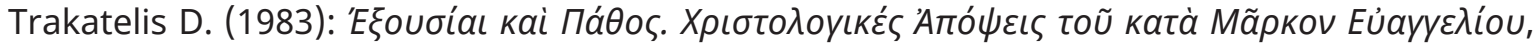
"Domos", Athens.

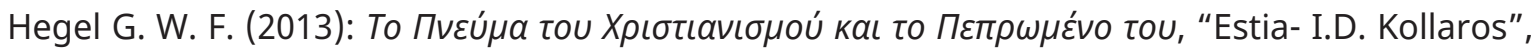
Athens. 